\title{
Clinicopathological Study of Cervical Cancer: A Retrospective Analysis
}

\author{
${ }^{1}$ Gopalakrishna Nandini, ${ }^{2}$ Jessica C Fernandes, ${ }^{3}$ Punuru Sindhu
}

\section{ABSTRACT}

Introduction: Cervical cancer remains the most common gynecological cancer among women in developing countries.

Objective: The objective was to analyze the clinical presentation and histopathological pattern of carcinoma cervix over a 3-year period.

Design: This was a retrospective analysis.

Results: The majority of the patients were between 40 and 50 years. Most of the patients presented at stage III. Squamous cell carcinoma was the most common histopathological pattern. Radiotherapy with concurrent chemotherapy was the modality of treatment.

Conclusion: The outcome significantly shows the inadequate screening program to detect preinvasive stage of carcinoma cervix.

Keywords: Carcinoma cervix, Chemotherapy, Histopathology, Radiotherapy, Squamous cell carcinoma.

How to cite this article: Nandini G, Fernandes JC, Sindhu P. Clinicopathological Study of Cervical Cancer: A Retrospective Analysis. J South Asian Feder Menopause Soc 2018;6(1):22-25.

\section{Source of support: Nil}

Conflict of interest: None

Date of received: 10 January 2018

Date of acceptance: 27 January 2018

Date of publication: August 2018

\section{INTRODUCTION}

Cervical cancer remains the most common gynecological cancer among women in developing countries. Worldwide, cervical cancer continues to be a significant health care problem. In general, higher incidences are found in developing countries and these countries contribute to $83 \%$ of reported cases annually.

\footnotetext{
${ }^{1}$ Professor, ${ }^{2}$ Assistant Professor, ${ }^{3}$ Junior Resident

${ }^{1-3}$ Department of Obstetrics and Gynecology, M. S. Ramaiah Medical College, Bengaluru, Karnataka, India

Corresponding Author: Gopalakrishna Nandini, Professor Department of Obstetrics and Gynecology, M. S. Ramaiah Medical College, Bengaluru, Karnataka, India, Phone: +919480059850, e-mail: nandinigopalakrishna@gmail.com
}

\section{Objectives}

A retrospective study of all patients with cancer cervix over a 3-year period was done from January 2012 to December 2014 at M. S. Ramaiah Hospital, a tertiary care center, to analyze the clinical presentation and histopathological pattern of the malignancy.

\section{Design}

This was a retrospective study.

\section{Significance}

The outcome of the analysis will help to take measures to diagnose the carcinoma at an early stage and to decrease the morbidity and mortality.

\section{MATERIALS AND METHODS}

This was a retrospective study carried out at M. S. Ramaiah Hospital. The aim was to analyze the clinical presentation and histopathological pattern of cervical carcinoma over a 3-year period from January 2012 to December 2014. The case files of all the histologically confirmed carcinoma were retrieved from the medical records department of the hospital and analyzed.

Information obtained included the demography (age, parity, occupation, educational status, and marital status), clinical history, clinical examination, and investigations (hematological, biochemical, and radiological) done before treatment. The staging, histopathology, and treatment were analyzed.

\section{Statistical Analysis}

Using the multivariate analysis, the association among age of the patient, clinical stage, histopathology, and treatment was studied. Using the Statistical Package for the Social Sciences software statistics, version 18 , data were analyzed using the descriptive statistics and frequency analysis. Cross-tabs were created between clinical staging and histopathology of carcinoma cervix.

\section{RESULTS}

During the study period, a total of 151 cases of carcinoma cervix were managed accounting for $47 \%$ of all gynecological cancers. 
About $96 \%$ of the patients belonged to low socioeconomic status. The common clinical presentation was discharge per vagina and postmenopausal bleeding

\section{DISCUSSION}

The study revealed that the incidence of carcinoma cervix is $47 \%$, which almost represents the national data of Bangladesh. ${ }^{1}$ Most of the carcinoma cervix patients were diagnosed at an advanced stage and similar observation was made by Dinshaw et al. ${ }^{2}$

In India, cancer cervix is one of the leading cancers and cause of death in women, hence emphasis should be given on screening and early diagnosis. ${ }^{3}$ Community sensitization and institution of countrywide screening programs will go a long way in reducing the incidence of this cancer among our women. ${ }^{4}$

Human papilloma virus (HPV) testing is another method utilized in developed countries which can be used among the developing countries. ${ }^{4}$ But its use may be limited by the cost and availability of the test kits. ${ }^{4}$ Keeping all these problems with tests, an attempt can be made on primary prevention using HPV vaccination. Ideally, HPV vaccination should cover a high percentage of the target population (preadolescent girls) if well implemented. ${ }^{4}$ But the weak and improperly coordinated health systems may not support wide-scale immunization.

Table 1: Age distribution of the patients

\begin{tabular}{cll}
\hline Age group (years) & Number & Percentage \\
\hline$<30$ & 3 & 1.98 \\
$30-39$ & 18 & 11.92 \\
$40-49$ & 59 & 39.07 \\
$50-59$ & 44 & 29.13 \\
$60-69$ & 24 & 15.89 \\
$>70$ & 3 & 1.98 \\
\hline
\end{tabular}

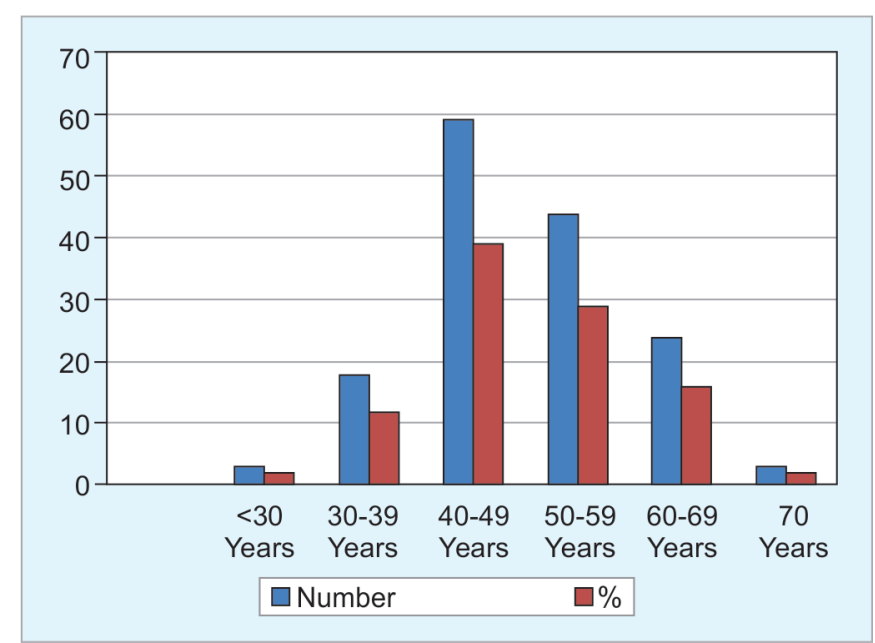

Graph 1: Age distribution of patients
Ideally, a combined strategy utilizing primary prevention in the form of HPV vaccination and secondary prevention in the form of screening and treatment of precursor disease is required.

The preinvasive stage lasts for a long period, and only a small proportion of cervical intraepithelial neoplasia (CIN) progresses to an invasive lesion. ${ }^{5}$

Majority of the patients were between 40-49 yrs constituting 39.07\% (Table 1 and Graph 1). In our study carcinoma cervix was more in parous women. $33.7 \%$ were para 5 and above (Table 2 and Graph 2).

The major presenting symptoms were vaginal discharge and postmenopausal bleeding. This is similar to findings from other studies (Uzoigwe and Seleye-Pubara 2004; Ijaiya et al. 2004; Olantuji and Sule-Odu 2005). ${ }^{1,6,7}$ Discharge per vagina was seen in $52.98 \%$ (Table 3 and Graph 3).

Majority of our patients presented to us in stage III. $50 \%$ of the patients presented with stage III disease (Table 4 and Graph 4). This is similar to the study done in Nigeria. Most of the carcinoma cervix patients were diagnosed at an advanced stage \& similar observation was made by Sankaranarayanan et al. ${ }^{8}$

Analysis of the histopathological pattern revealed squamous cell variety and of large cell type. This was the histopathology in majority of the studies done in

Table 2: The parity distribution. The majority of the patients were grand multipara

\begin{tabular}{lll}
\hline Parity & Number & Percentage \\
\hline Para 2 & 18 & 11.9 \\
Para 3/4 & 32 & 21.19 \\
Para 5/> & 51 & 33.77 \\
\hline
\end{tabular}

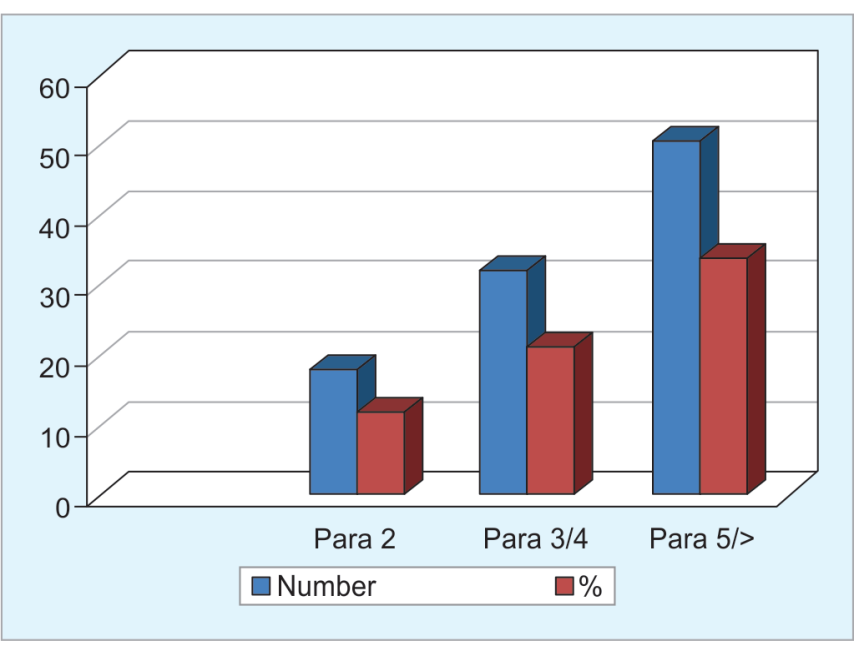

Graph 2: Parity distribution 
Table 3: Clinical symptoms with which the patients presented to the hospital

\begin{tabular}{lll}
\hline Symptoms & Number & Percentage \\
\hline Discharge per vagina & 80 & 52.98 \\
Postmenopausal bleeding & 71 & 47.01 \\
Abdominal pain & 61 & 40.39 \\
Postcoital bleeding & 21 & 13.90 \\
Weight loss & 14 & 9.27 \\
\hline
\end{tabular}

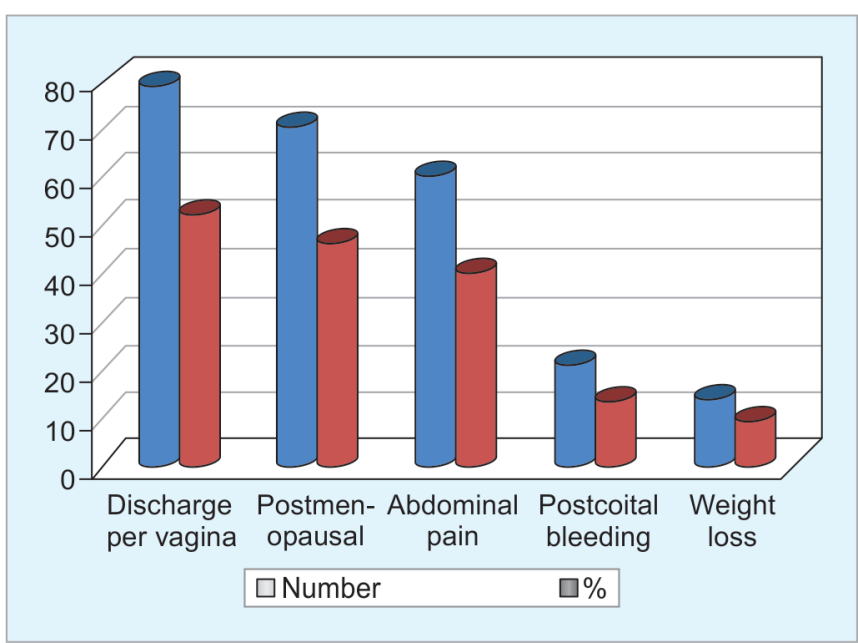

Graph 3: Distribution of patients based on symptoms

Table 5: Histological types of cervical carcinoma. Among them, $95.36 \%$ were of squamous cell carcinoma of large cell variety

\begin{tabular}{lll}
\hline Histological type & Number & Percentage \\
\hline $\begin{array}{l}\text { Squamous cell carcinoma (large cell } \\
\text { nonkeratinizing) }\end{array}$ & 134 & 88.74 \\
$\begin{array}{l}\text { Squamous cell carcinoma (large cell } \\
\text { keratinizing) }\end{array}$ & 10 & 6.62 \\
$\begin{array}{l}\text { Adenocarcinoma well differentiated } \\
\text { Papillary adenocarcinoma }\end{array}$ & 5 & 3.31 \\
Adenosquamous carcinoma & 1 & 0.66 \\
\hline
\end{tabular}

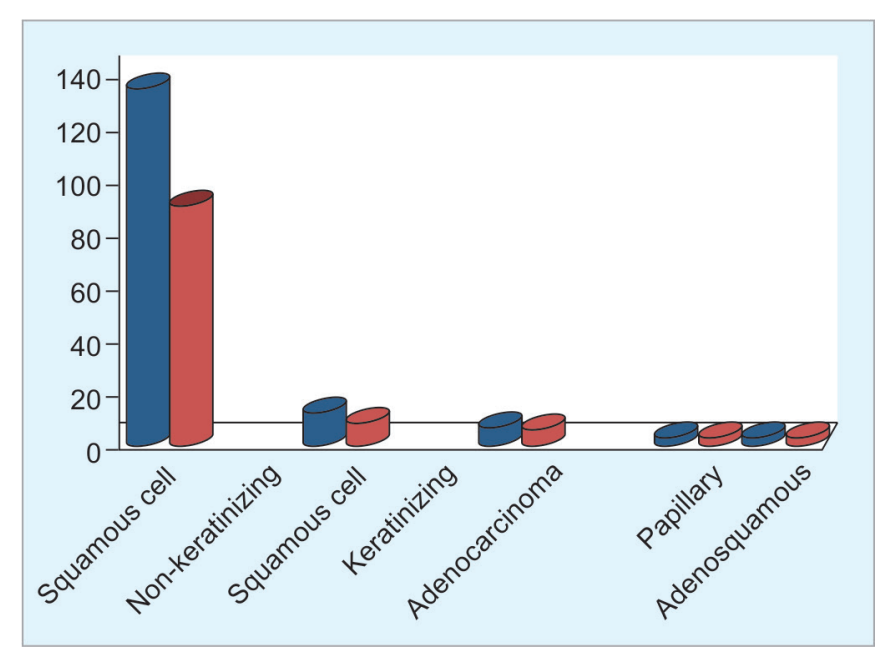

Graph 5: The histological types of carcinoma cervix
Table 4: Clinical stage at the time of presentation

\begin{tabular}{lll}
\hline Stage of presentation & Number & Percentage \\
\hline Ia & 4 & 2.64 \\
Ib & 4 & 2.64 \\
Ila & 7 & 4.63 \\
Ilb & 49 & 32.45 \\
IIla & 12 & 7.94 \\
IIIb & 63 & 41.72 \\
IVa & 11 & 7.28 \\
\hline
\end{tabular}

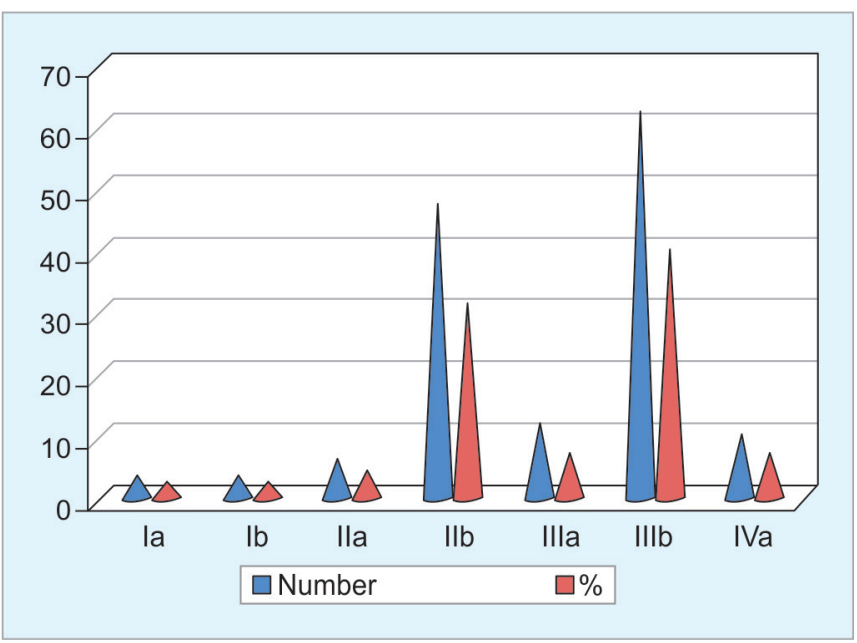

Graph 4: Distribution of patients based on stage at the time of presentation

Table 6: Treatment modality received

\begin{tabular}{lll}
\hline Modality of treatment & Number & Percentage \\
\hline Radiotherapy plus chemotherapy & 130 & 86 \\
Palliative radiotherapy & 11 & 7.28 \\
Surgery & 9 & 5.96 \\
Surgery + radiation therapy and chemo & 1 & 0.66
\end{tabular}

the developing countries. Our study revealed $88.74 \%$ had squamous cell carcinoma, large cell nonkeratinising (Table 5 and Graph 5).

As majority of the patients presented to us in the late stage, 86\% (Table 6 and Graph 6) radiotherapy was the main treatment modality. Radiotherapy was EBRT of $4500 \mathrm{cGY}$ in 25 fractions. The surgical treatment was Wertheim's hysterectomy. Chemotherapy was platinum based. Palliative care was EBRT30GY in 10 fractions.

The study revealed that the incidence of carcinoma cervix is $47 \%$ which almost represents the national data of Bangladesh. ${ }^{9}$

\section{CONCLUSION}

In conclusion, major steps need to be taken to decrease the incidence of carcinoma cervix. Early diagnosis of the preinvasive stage by screening and appropriate treatment 


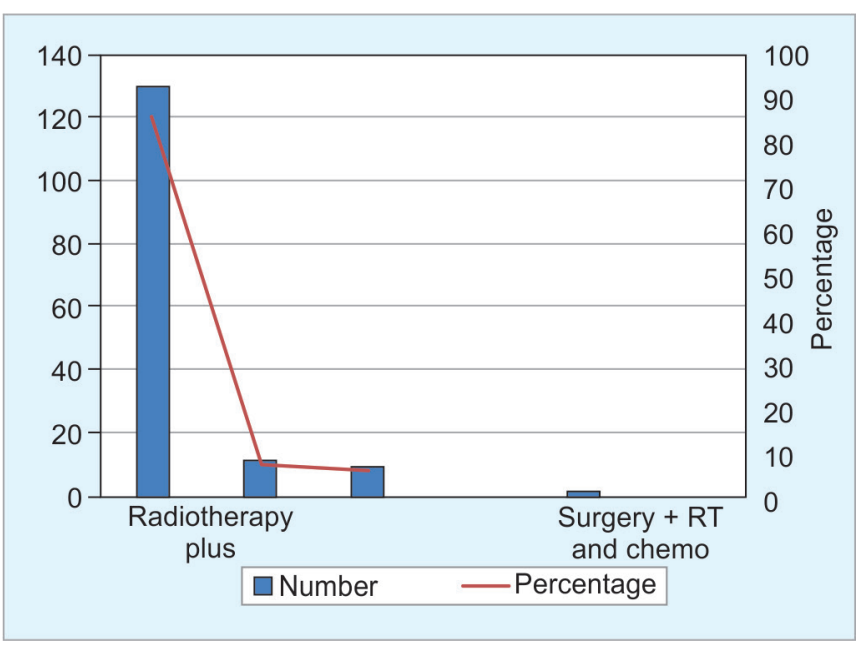

Graph 6: Distribution based on modality of treatment

should be instituted at the preinvasive stage. Health education about family planning is to be advised. Screening program should be made free of cost or at affordable cost. Radiotherapy units are to be made available at least in major districts of all states and this will help in reducing the incidence and mortality due to carcinoma cervix. A major breakthrough will be to make compulsory HPV vaccination to all preadolescent girls, thereby helping to reduce the incidence of carcinoma cervix in future.

\section{REFERENCES}

1. WHO/ICO Information Centre on HPV and Cervical Cancer (HPV Information Centre). Human papillomavirus and related cancers in Bangladesh. Summary report 2010 (Internet). [Cited 2012 Mar 3]. 2010.
2. Dinshaw K, Mishra G, Shastri S, Badwe R, Kerkar R, Ramani S, Thakur M, Uplap P, Kakade A, Gupta S, et al. Determinants of compliance in a cluster randomized controlled trial on screening of breast and cervix cancer in Mumbai, India. I. Compliance to screening. Oncology 2007;73(3-4):145-153.

3. Banu PA, Rukhsana N, Yasmin J, Nahar L, Malik SR. Analysis on the incidence, staging and treatment of carcinoma cervix at Delta Medical College and Hospital of Bangladesh. Delta Med Col J 2013 Jul;1(2):31-36.

4. Ikechebelu JI, Onyiaorah IV, Ugboaja JO, Anyiam DCD, Eleje GU. Clinicopathological analysis of cervical cancer seen in a tertiary care facility in Nnewi, south-east Nigeria. J Obstet Gynaecol 2010 Apr;30(3):299-301.

5. Uzoigwe SA, Seleye-Fubara D. Cancers of the uterine cervix in Port-Harcourt, Rivers State: a 13-year clinico-pathological review. Niger J Med 2004 Apr-Jun;13(2):110-113.

6. Ijaiya MA, Aboyeji PA, Buhari MO. Cancer of the cervix in Ilorin, Nigeria. West Afr Med J 2004 Oct-Dec;23(4):319-322.

7. Olatunji AO, Sule-Odu AO. Cancer of the cervix. Niger Postgrad Med J 2005 Dec;12(4):308-311.

8. Sankaranarayanan R, Esmy PO, Rajkumar R, Muwonge R, Swaminathan R, Shanthakumari S, Fayette JM, Cherian J. Effect of visual screening on cervical cancer incidence and mortality in Tamil Nadu, India: a cluster randomised trial. Lancet 2007 Aug;370(9585):398-406.

9. Nandi M, Mandal A, Asthana A. Retrospective analysis of patients with cancer of the cervix attending a radiotherapy outpatient department: experience from a university-based hospital in eastern Uttar Pradesh, India. South Afr J Gynaecol Oncol 2015 Mar;7(1):5-12.

10. Richardson, DL. Cervical cancer. Chapter 30. In: Schorge JO, Hoffman BL, Bradshaw KD, Halvorson LM, Schaffer JI, Corton MM, editors. Williams Gynecology. 1st ed. New York: McGraw-Hill companies, Inc.; 2008. p. 769-793.

11. Berek, JS. Cervical and vaginal cancer. Chapter 34. In: Berek JS, editor. Berek \& Novak's Gynaecology. 14th ed. Philadelphia (PA): Lippincott Williams \& Wilkins; 2007. p. 1404-1456. 